\title{
Diversity and effective population size of four horse breeds from microsatellite DNA markers in South-Central Mexico
}

\author{
José Fernando Vázquez-Armijo ${ }^{1}$, Gaspar Manuel Parra-Bracamonte ${ }^{2}$, Miguel Abraham Velazquez ${ }^{3}$, \\ Ana María Sifuentes-Rincón ${ }^{2}$, José Luis Tinoco-Jaramillo ${ }^{4}$, Pascuala Ambriz-Morales ${ }^{2}$, \\ Williams Arellano-Vera ${ }^{2}$, and Victor Ricardo Moreno-Medina ${ }^{2}$ \\ ${ }^{1}$ Centro Universitario UAEM Temascaltepec, Universidad Autónoma del Estado de México (UAEM). Km. 67.5 \\ Carretera Federal Toluca-Tejupilco, Código Postal 51300, Temascaltepec, Estado de México, Mexico \\ ${ }^{2}$ Centro de Biotecnología Genómica, Instituto Politécnico Nacional, Boulevard del Maestro, esquina Elías Piña, \\ Colonia Narciso Mendoza, Código Postal 88710, Reynosa, Tamaulipas, Mexico \\ ${ }^{3}$ School of Agriculture, Food \& Rural Development, Newcastle University, \\ Newcastle upon Tyne NE1 7RU, UK \\ ${ }^{4}$ Facultad de Medicina Veterinaria y Zootecnia, Universidad Nacional Autónoma de México. Avenida Unidad \\ 3000, Circuito Exterior, Ciudad Universitaria, Delegación Coyoacán, Código Postal 04510, \\ Distrito Federal, Mexico \\ Correspondence to: Gaspar Manuel Parra-Bracamonte (pabraman@ hotmail.com)
}

Received: 18 October 2016 - Revised: 19 April 2017 - Accepted: 4 May 2017 - Published: 8 June 2017

\begin{abstract}
The South-Central region of Mexico has experienced a sizeable introduction of purebred horses for recreational aims. A study was designed to assess effective population sizes and genetic diversity and to verify the genetic integrity of four horse breeds. Using a 12-microsatellite panel, Quarter Horse, Azteca, Thoroughbred and Creole (CRL) horses were sampled and analysed for diversity and genetic structure. Genetic diversity parameters showed high numbers of heterozygous horses but small effective population sizes in all breeds. Population structure results suggested some degree of admixture of CRL with the other reference breeds. The highly informative microsatellite panel allowed the verification of diversity in introduced horse populations and the confirmation of small effective population sizes, which suggests a risk for future breed integrity.
\end{abstract}

\section{Introduction}

Since its reintroduction to the Americas during the time of Spanish colonization (Luís et al., 2006; Jimenez et al., 2012), the horse has played a significant role in the history and culture of Mexico (LeCompte, 1985; Griffith and Fernández, 1988; Nájera-Ramírez, 1994; Palomar, 2004; Pineda and Díaz, 2012). Mexico has one of the largest horse populations in the world (da Mota and Regitano, 2012) with a substantial number of mixed-breed horses used for agricultural, farming, transportation, tourism and patrolling (i.e. mounted police) purposes (Loroño-Pino et al., 2003; Velázquez-Beltrán et al., 2011; Cantú-Martínez et al., 2012; Sánchez-Casanova et al., 2014). However, a significant number of horses in
Mexico are purebred, mainly promoted by four official horse breeding associations that manage the studbooks for breeds such as the Pura Raza Española, Lusitano, Azteca, Westphalian, Holsteiner, Dutch and Belgian warmbloods, Selle Français, Hanoverian, Thoroughbred, Quarter Horse and Arabian (CONARGEN, 2017; Domínguez-Viveros et al., 2014). Purebred horses in Mexico are used for several equestrian events, including horse racing, Olympic disciplines and traditional equestrian competitions known as charreadas (Palomar, 2004; Cantú-Martínez et al., 2012; Pineda and Díaz, 2012; Rodríguez-Sánchez et al., 2015). Additionally, a barely documented, but broadly extended use for these purebred animals is the training for horse dancing competitions during traditional regional festivities. Another rele- 
vant horse breed in Mexico is the Creole (Criollo) horse, which also plays a significant role in farming and Mexican equestrian traditions (Domínguez-Sánchez et al., 2015). The Creole breed is derived from feral horse populations introduced during the first Spanish expeditions to the Americas (Domínguez-Sánchez et al., 2015), similar to other Creole breeds in South America (Kelly et al., 2002; Mirol et al., 2002; Jimenez et al., 2012).

The central region of Mexico has experienced a sizeable introduction of purebred horses. However, a potential problem with these introductions is the maintenance of breed integrity. Conservation of breed identity and adequate effective population size is pivotal for sound breeding management in any species, and genetic markers such as short tandem repeat (STR) loci (i.e. microsatellites) have been extensively used to examine genetic diversity and breed characterization in horse populations worldwide (Aberle et al., 2004; Marletta et al., 2006; Druml et al., 2007; Zuccaro et al., 2008; Felicetti et al., 2010; Chauhan et al., 2011; Ling et al., 2011; Takasu et al., 2012; Fornal et al., 2013; Berber et al., 2014). In this study, we used 17 microsatellite DNA markers to provide genetic diversity and effective population size of four horse breeds of economic and cultural importance in Mexico.

\section{Material and methods}

\subsection{Animals and sample collection}

Samples of approximately 50 hair follicles were collected from male Quarter Horse (QHR, $n=19$ ), Azteca (AZT, $n=24$ ), Thoroughbred (THB, $n=15$ ) and Creole (CRL, $n=32$ ) horses in 30 different ranches from the southern region of the State of México, in South-Central Mexico. The samples were preserved in marked paper envelopes under dry conditions until their processing. The sampled animals were generally maintained in closed groups and often used as stallions in different regional ranches. Although some of the individual animals were recently introduced, their origin is unknown.

\subsection{DNA extraction and PCR conditions}

Genomic DNA was extracted with the GenElute Mammalian Genomic DNA Kit (Cat. G1N350, Sigma-Aldrich Co. LLC, St. Louis, Missouri, USA) following manufacturer's instructions. Agarose gels (1.5\%) and Lambda DNA Gibco Brl $\lambda$ weight standards were used for verification of DNA integrity. DNA concentration was measured with a NanoDrop 2000c spectrophotometer (Thermo Fisher Scientific v1.1.). Genotyping of samples was performed using the 17-microsatellite panel recommended by the International Society for Animal Genetics (ISAG) for identity and parentage testing (Table 1) (van de Goor et al., 2010). Polymerase chain reaction (PCR) conditions were optimized from the recommended StockMarks ${ }^{\circledR}$ for Horses kit protocol (Applied Biosystems,
Foster City, CA, USA). Genotyping was carried out in an ABI3130 genetic analyser with a $50 \mathrm{~cm}$ capillary (Applied Biosystems, Foster City, CA, USA). Based on the molecular weight marker, allele sizes were assigned to each individual. The X-linked locus LEX3 was excluded from the analysis.

\subsection{Statistical analysis}

Polymorphic information content (PIC) and combined exclusion probabilities (EPs) were computed with CERVUS 3.0.3. (Kalinowski et al., 2007). Further analysis considered null allele frequency $(<0.02)$ and Hardy-Weinberg equilibrium to maintain loci; then, HMS1, ASB17, HMS3 and VHL20 were excluded from the analysis. Expected (HE) and observed (HO) heterozygosity, allelic richness (AR) and inbreeding coefficients (FIS) were computed with FSTAT v2.9.3 (Goudet, 1995).

The effective population sizes $(\mathrm{Ne})$ and their confidence intervals $(95 \%)$ were estimated by linkage disequilibrium (LD) and the molecular co-ancestry method (CM), with the NeEstimator v2.01 software (Do et al., 2014). An individual assignment analysis was performed on the reference population (QHR, AZT, THB and CRL) using a Bayesian method proposed by Baudouin and Lebrun (2001), considering an assignment threshold of 0.01 for assignment scores; this procedure was computed in the GeneClass 2.0 software (Piry et al., 2004). Additionally, a population inference analysis was performed using STRUCTURE 2.3.4 (Pritchard et al., 2000) using a burning period of 50000 iterations and a run length of 200000 Markov chain Monte Carlo replications. STRUCTURE HARVESTER software (Earl and vonHoldt, 2012) was subsequently used to infer Delta $K$.

\section{Results}

The microsatellite panel was highly informative, with PIC ranging from 0.518 to 0.860 (Table 1), very high individual combined exclusion probabilities in the four evaluated populations (EP > 0.999) and individual EP ranging from 0.766 to 0.971 for HMS1 and ASB23 loci, respectively. The mean number of alleles per locus was 9.41 .

The four breeds showed heterozygosity values around 0.800 and lower, with the highest HE values observed in the CRL and AZT populations (Table 2). All HO values were higher than their corresponding HE values and the higher values were estimated in THB. Although values for AR were similar between the four breeds, the highest and the lowest values were found in the CRL and THB groups, respectively (Table 2). Values of FIS were negative and near zero, directly related to heterozygosity estimates. The estimated $\mathrm{Ne}$ values were low and varied from 1.0 to 14.4 for the THB and CRL breeds, respectively, by LD method. Whereas, the higher $\mathrm{Ne}$ values from the CM method was estimated for QHR. Both methods provided low but different estimations of $\mathrm{Ne}$ for 
Table 1. Microsatellite panel recommended by ISAG and used for genetic analysis of four horse breeds in South-Central Mexico.

\begin{tabular}{|c|c|c|c|c|c|}
\hline Loci & Sequence and repeated motif & $\begin{array}{l}\text { GenBank } \\
\text { accession }\end{array}$ & $\begin{array}{r}\text { Allelic } \\
\text { range }\end{array}$ & $\mathrm{PIC}^{3}$ & $1-\mathrm{EP}^{4}$ \\
\hline AHT4 & $(\mathrm{AC})_{n} \mathrm{AT}(\mathrm{AC})_{n}$ & Y07733 & $144-162$ & 0.820 & 0.045 \\
\hline AHT5 & $(\mathrm{GT})_{n}$ & Y07732 & $130-148$ & 0.817 & 0.046 \\
\hline ASB2 & $(\mathrm{GT})_{n}$ & X93516 & $238-260$ & 0.849 & 0.033 \\
\hline ASB17 & $(\mathrm{AC})_{n}$ & X93531 & $104-116$ & 0.750 & 0.079 \\
\hline ASB23 & $(\mathrm{TG})_{n}$ & Y935372 & 118-208 & 0.860 & 0.029 \\
\hline CA $425^{1}$ & $(\mathrm{GT})_{n}$ & U67406 & $224-246$ & 0.745 & 0.078 \\
\hline HMS1 & $(\mathrm{TG})_{n}$ & X74630 & $168-178$ & 0.518 & 0.234 \\
\hline HMS2 & $(\mathrm{CA})_{n}$ & X74631 & $220-236$ & 0.721 & 0.093 \\
\hline HMS3 & $(\mathrm{TG})_{2}(\mathrm{CA})_{2} \mathrm{TC}(\mathrm{CA})_{n}$ & $\mathrm{X} 74632$ & $146-170$ & 0.834 & 0.039 \\
\hline HMS6 & $(\mathrm{GT})_{n}$ & X74635 & $154-170$ & 0.769 & 0.067 \\
\hline HMS7 & $(\mathrm{AC})_{2}(\mathrm{CA})_{n}$ & X74636 & $118-186$ & 0.829 & 0.041 \\
\hline HTG4 & $(\mathrm{TG})_{n} \mathrm{AT}(\mathrm{AG})_{5} \mathrm{AAG}(\mathrm{GA})_{5} \mathrm{ACAG}(\mathrm{AGGG})_{3}$ & AF169165 & $118-162$ & 0.629 & 0.150 \\
\hline HTG6 & $(\mathrm{TG})_{n}$ & AF169167 & $74-102$ & 0.823 & 0.044 \\
\hline HTG7 & $(\mathrm{GT})_{n}$ & AF169291 & $118-128$ & 0.728 & 0.093 \\
\hline HTG10 & $(\mathrm{TG})_{n}[\mathrm{C} / \mathrm{T}]$ & AF169294 & $86-106$ & 0.826 & 0.041 \\
\hline VHL20 & $(\mathrm{TG})_{n}$ & X75970 & $86-102$ & 0.801 & 0.054 \\
\hline $\operatorname{LEX}^{5}$ & $(\mathrm{TG})_{n}$ & AF075607 & $138-162$ & 0.816 & 0.045 \\
\hline
\end{tabular}

${ }^{1}$ UCDEQ425. ${ }^{2}$ NW_001799714, sequence currently obsolete in GenBank (Raudsepp et al., 2008). ${ }^{3}$ Polymorphic information content. ${ }^{4} \mathrm{PE}$ : individual exclusion probability. ${ }^{5} \mathrm{X}$-linked locus excluded from the analysis.

Table 2. Genetic diversity parameters and effective population size of four horse breeds in South-Central Mexico.

\begin{tabular}{lrrrrrr}
\hline Breed & $H_{\mathrm{E}}$ & $H_{\mathrm{O}}$ & $\mathrm{AR}$ & $F_{\mathrm{IS}}$ & $\mathrm{LDN}_{\mathrm{e}}$ & MCN $_{\mathrm{e}}$ \\
\hline QHR & 0.762 & 0.847 & 5.94 & -0.078 & $2.5(2.2-2.9)$ & $13.9(2.9-33.4)$ \\
AZT & 0.765 & 0.826 & 6.35 & -0.058 & $8.5(6.9-10.5)$ & $5.6(4.0-7.5)$ \\
THB & 0.733 & 0.877 & 5.16 & -0.163 & $1.0(0.8-1.1)$ & $6.9(4.1-10.5)$ \\
CRL & 0.806 & 0.820 & 7.86 & 0.024 & $14.4(12.4-16.7)$ & $7.9(5.5-10.7)$ \\
\hline
\end{tabular}

$\mathrm{QHR}=$ Quarter Horse; $\mathrm{AZT}=$ Azteca; $\mathrm{THB}=$ Thoroughbred $\mathrm{CRL}=$ Creole, $H_{\mathrm{E}}=$ expected

heterozygosity; $H_{\mathrm{O}}=$ observed heterozygosity; $\mathrm{AR}=$ allelic richness; $F_{\mathrm{IS}}=$ population inbreeding

coefficient. Effective population size ( $95 \%$ confidence interval) estimated with the linkage disequilibrium

$\left(\mathrm{LDN}_{\mathrm{e}}\right)$ and molecular co-ancestry $\left(\mathrm{MCN}_{\mathrm{e}}\right)$ method.

analysed breed groups; however, in general, lower effective population estimates were observed in THB (Table 2).

Genetic assignment analysis showed no possible pattern of genetic flow between assessed breeds since all individuals were assigned to their reference-compared populations. However, a resemblance between breeds was suggested by the population structure analysis; the Evanno's test indicated that the most informative number of subpopulations were $K=2$ (Fig. 1).

\section{Discussion}

Documentation in the specialized literature on the genetic diversity and structure of current horse breeds in Mexico is scarce. However, it is well known that some breeds were introduced for different recreational purposes. It is important to highlight that the population analysed in the present study has a significant relevance for breeding practices as it is com- posed of stallions and young male breeding candidates that will be used for breed dissemination locally and regionally by natural breeding and/or with the use of assisted reproduction (e.g. artificial insemination).

In some genetic diversity studies with microsatellites the number of horses analysed per breed ranged from 17 to 24 (Aberle et al., 2004; Solis et al., 2005; Marletta et al., 2006; Burócziová and Ř́ha, 2009; Leroy et al., 2009; Chauhan et al., 2011; Ling et al., 2011; van de Goor et al., 2011; Prystupa et al., 2012; Khanshour et al., 2013; Berber et al., 2014), which is similar to the number of animals used per breed in the present study.

Consistent with the total average number of alleles observed, the allelic richness estimations by breed were low, promoted perhaps by the reduced sample size or possible founder events (Greenbaum et al., 2014). Since AR is considered a useful indicator of population size reduction and past bottleneck events (Nei et al., 1975), the implication for our sampled breeds could be more important as no informa- 

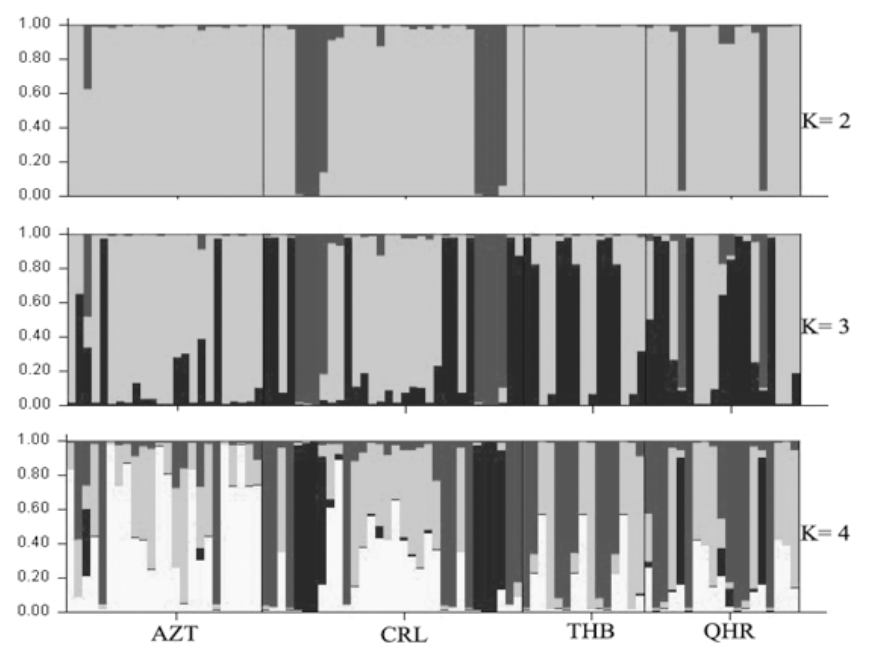

Figure 1. Population structure graphics showing $K 2$ to $K 4$ clustering of four horse breeds in South-Central Mexico.

tion on the initial allelic composition available could suggest a deep reduction in original diversity. Is important to observe that a decrease in the allelic richness could lead to a reduction in the population's potential to adapt to future environmental changes, hence the importance for conservation management (Greenbaum et al., 2014).

Heterozygosity was slightly higher than that reported for Thoroughbred horses (Cunningham, et al., 2001; GlowatzkiMullis, et al., 2006; van de Goor et al., 2011) and Quarter Horses (Luis et al., 2007) in previous studies with the same or similar loci and could be due in part to the random origin of the samples (different ranches). Similarly, lower heterozygosity values were reported in Argentine, Brazilian, Chilean and Venezuelan CRL horses (Cothran et al., 2011).

The negative FIS values found in the four breeds indicate high intra-breed variability and lower heterozygosity. Petersen et al. (2013), using whole-genome single-nucleotide polymorphism data, suggested that horse breeds with low within-breed diversity, such as Thoroughbred and Quarter Horse, may be related to population bottlenecks, intense selective pressure or closed conditions due to their long breed histories. For the Thoroughbred breed, they reported a high mean individual inbreeding coefficient (larger than 10\%) (Petersen et al., 2013). In the present study, high heterozygosis showed no current inbreeding risk. Nevertheless, the two methods used for Ne estimation consistently indicated very low effective populations. However, the LD method was suggested to have estimation bias when used on small samples (England et al., 2006). Recently, improvement in contemporary effective population size estimation methods (e.g. NeEstimator v.2.0) suggests highly reliable estimates of Ne under migration (LD method) and no migration (MC method) assumptions, even with small samples (Gilbert and Whitlock,
2015). Perhaps further and wider sampling would confirm the present results.

In general, the present results confirmed the usefulness of microsatellites in the assessment of genetic diversity and integrity of different horse breeds around the world (Aberle et al., 2004; Solis et al., 2005; Marletta et al., 2006; Luis et al., 2007; Burócziová and Ř́na, 2009; Leroy et al., 2009; Chauhan et al., 2011; Ling et al., 2011; van de Goor et al., 2011; Conant et al., 2012; Prystupa et al., 2012; Khanshour et al., 2013; Berber et al., 2014). Genetic characterization helps to assure breed integrity and to assign individuals to defined populations (Glowatzki-Mullis et al., 2006). In the present assessment, considering the population structure results showing the two most likely conforming populations, and the partially mixed CRL population could suggest some degree of genetic flow and resemblance that could be explained by the crossbred strategies used in the creation of the CRL breed, leading to a breed that is not well defined.

Therefore, both records on breeding management and genetic monitoring by genetic markers may be necessary to avoid undesirable consequences of effective population size reduction and breed dilution. Together with genetic information in classical horse breeding and recent achievements in population and conservation genetics (Achmann, et al., 2004; Hasler et al., 2011; Janova et al., 2013), the results of the present study have implications for better development of management strategies for local populations such as the breeds assessed here. As such, a comprehensive approach would include a periodical assessment of known local populations to ensure the acceptable effective population size and breed integrity documentation of genetic flow and reproductive management, as most of the introduced animals in the studied area are used as breeders, being relatively expensive and highly valued animals.

In conclusion, using an informative microsatellite panel, we verified diversity indicators of four introduced horse populations and confirmed small effective population sizes as a risk for future breed integrity if not considered during breeding management. Attention to these indicators will avoid undesirable consequences in the breed integrity of these popular animals.

Data availability. Data are available by a mailed request to the corresponding author.

Competing interests. The authors declare that they have no conflict of interest.

Edited by: S. Maak

Reviewed by: two anonymous referees 


\section{References}

Aberle, K. S., Hamann, H., Drögemüller, C., and Distl, O.: Genetic diversity in German draught horse breeds compared with a group of primitive, riding and wild horses by means of microsatellite DNA markers, Anim. Genet., 35, 270-277, https://doi.org/10.1111/j.1365-2052.2004.01166.x, 2004.

Achmann, R., Curik, I., Dovc, P., Kavar, T., Bodo, I., Habe, F., Marti, E., Sölkner, J., and Brem, G.: Microsatellite diversity, population subdivision and gene flow in the Lipizzan horse, Anim. Genet., 35, 285-292, https://doi.org/10.1111/j.13652052.2004.01157.x, 2004.

Baudouin, L. and Lebrun, P.: An Operational Bayesian Approach for the Identification of Sexually Reproduced CrossFertilized Populations using Molecular Markers, Proc. Int. Symp. on Molecular Markers, edited by: Doré, D. and Baril, Montpellier, FRA, 3 June 2000-3 August 2000, 546, 81-94, https://doi.org/10.17660/ActaHortic.2001.546.5, 2001.

Berber, N., Gaouar, S., Leroy, G., Kdidi, S., Tabet, A. N., and Saïdi, M. N.: Molecular characterization and differentiation of five horse breeds raised in Algeria using polymorphic microsatellite markers, J. Anim. Breed. Genet., 131, 387-394, https://doi.org/10.1111/jbg.12092, 2014.

Burócziová, M. and Ř́íha, J.: Horse breed discrimination using machine learning methods, J. Appl. Genet., 50, 375-377, https://doi.org/10.1007/BF03195696, 2009.

Cantú-Martínez, M. A., Segura-Correa, J. C., Silva-Páez, M. L., Avalos-Ramírez, R., and Wagner, G. G.: Prevalence of antibodies to Theileria equi and Babesia caballi in horses from northeastern Mexico, J. Parasitol., 98, 869-870, https://doi.org/10.1645/GE3064.1, 2012.

Chauhan, M., Gupta, A. K., and Dhillon, S.: Genetic diversity and population structure of three Indian horse breeds, Mol. Biol. Rep., 38, 3505-3511, https://doi.org/10.1007/s11033-010-0461z, 2011.

CONARGEN: Equinos. Consejo Nacional de los Recursos Genéticos Pecuarios, available at: http://dev4.co/conargen/category/ socios/equinos-socios/, last access: 5 May 2017.

Conant, E. K., Juras, R., and Cothran, E. G.: A microsatellite analysis of five Colonial Spanish horse populations of the southeastern United States, Anim. Genet., 43, 53-62, https://doi.org/10.1111/j.1365-2052.2011.02210.x, 2012.

Cothran, E. G., Canelon, J. L., Luis, C., Conant, E., and Juras, R.: Genetic analysis of the Venezuelan Criollo horse, Genet. Mol. Res., 10, 2394-2403, https://doi.org/10.4238/2011.October.7.1, 2011

Cunningham, E. P., Dooley, J. J., Splan, R. K., and Bradley, D. G.: Microsatellite diversity, pedigree relatedness and the contributions of founder lineages to thoroughbred horses, Anim. Genet., 32, 360-364, https://doi.org/10.1046/j.1365-2052.2001.00785.x, 2001.

da Mota, M. D. S. and Regitano, L. C. A.: Some peculiarities of horse breeding, in: Livestock Production, edited by: Javed, K., InTech, Rijeka, Croatia, EU, 33-46, https://doi.org/10.5772/50519, 2012.

Do, C., Waples, R. S., Peel, D., Macbeth, G. M., Tillett, B. J., and Ovenden, J. R.: NeEstimator v2: re-implementation of software for the estimation of contemporary effective population size (Ne) from genetic data, Mol. Ecol. Res., 14, 209-214, https://doi.org/10.1111/1755-0998.12157, 2014.

Domínguez-Sánchez, C., Cervantes, P., Pérez-Rico, A., Delgado, J. V., Jiménez, L. M., Aguirre, L., Brandariz, C., Nuñez, L., Cortés, O., Farman, S., Costa, M. R., Kelly, L., and Vega-Pla, J. L.: Estructura genética del caballo local de Veracruz, México, usando microsatélites, Acta Iberoamericana Conserv. Anim., 6, 192-200, 2015.

Domínguez-Viveros, J., Rodríguez-Almeida, F. A., and OrtegaGutiérrez, J. Á.: Consanguinidad and estimación de parámetros genéticos para morfología del caballo Lusitano en México, Arch Zootec., 63, 37-44, 2014.

Druml, T., Curik, I., Baumung, R., Aberle, K., Distl, O., and Sölkner, J.: Individual-based assessment of population structure and admixture in Austrian, Croatian and German draught horses, Heredity, 98, 114-122, https://doi.org/10.1038/sj.hdy.6800910, 2007.

Earl, D. A. and vonHoldt, B. M.: STRUCTURE HARVESTER: a website and program for visualizing STRUCTURE output and implementing the Evanno method, Cons. Gen. Res., 4, 359-361, https://doi.org/10.1007/s12686-011-9548-7, 2012.

England, P. R., Cornuet, J. M., Berthier, P., Tallmon, D. A., and Luikart, G.: Estimating effective population size from linkage disequilibrium: severe bias in small samples, Cons. Genet., 7, 303-308, https://doi.org/10.1007/s10592-005-9103-8, 2006.

Felicetti, M., Lopes, M. S., Verini-Supplizi, A., Machado, A. C., Silvestrelli, M., Mendonça, D., and Distl, O.: Genetic diversity in the Maremmano horse and its relationship with other European horse breeds, Anim. Genet., 41, 53-55, https://doi.org/10.1111/j.1365-2052.2010.02102.x, 2010.

Fornal, A., Radko, A., and Piestrzyńska-Kajtoch, A.: Genetic polymorphism of Hucul horse population based on 17 microsatellite loci, Acta Biochim. Pol., 60, 761-764, 2013.

Gilbert, K. J. and Whitlock, M. C.: Evaluating methods for estimating local effective population size with and without migration, Evolution, 69, 2154-2166, https://doi.org/10.1111/evo.12713, 2015.

Glowatzki-Mullis, M. L., Muntwyler, J., Pfister, W., Marti, E., Rieder, S., Poncet, P. A., and Gaillard, C.: Genetic diversity among horse populations with a special focus on the Franches-Montagnes breed, Anim. Genet., 37, 33-39, https://doi.org/10.1111/j.1365-2052.2005.01376.x, 2006.

Goudet, J.: FSTAT (version 1.2): a computer program to calculate F-statistics, J. Hered., 86, 485-486, 1995.

Greenbaum, G., Templeton, A. R., Zarmi, Y., and BarDavid, S.: Allelic Richness following Population Founding Events - A Stochastic Modeling Framework Incorporating Gene Flow and Genetic Drift, PLoS ONE, 9, e115203, https://doi.org/10.1371/journal.pone.0115203, 2014.

Griffith, J. S. and Fernández, C.: Mexican horse races and cultural values: the case of Los Corridos del Merino, West, Folklore, 47, 129-151, https://doi.org/10.2307/1500127, 1988.

Hasler, H., Flury, C., Menet, S., Haase, B., Leeb, T., Simianer, H., Poncet, P. A., and Rieder, S.: Genetic diversity in an indigenous horse breed-implications for mating strategies and the control of future inbreeding, J. Anim. Breed. Gen., 128, 394-406, https://doi.org/10.1111/j.1439-0388.2011.00932.x, 2011.

Janova, E., Futas, J., Klumplerova, M., Putnova, L., Vrtkova, I., Vyskocil, M., Frolkova, P., and Horin, P.: Genetic diversity and 
conservation in a small endangered horse population, J. Appl. Genet., 54, 285-292, https://doi.org/10.1007/s13353-013-01513, 2013.

Jimenez, L. M., Mendez, S., Dunner, S., Cañón, J., and Cortés, O.: Colombian Creole horse breeds: same origin but different diversity, Genet. Mol. Biol., 35, 790-796, https://doi.org/10.1590/S1415-47572012005000064, 2012.

Kalinowski, S. T., Taper, M. L., and Marshall, T. C.: Revising how the computer program CERVUS accommodates genotyping error increases success in paternity assignment, Mol. Ecol., 16, 1099-1106, https://doi.org/10.1111/j.1365-294X.2007.03089.x, 2007.

Kelly, L., Postiglioni, A., De Andrés, D. F., Vega-Plá, J. L., Gagliardi, R., Biagetti, R., and Franco J.: Genetic characterisation of the Uruguayan Creole horse and analysis of relationships among horse breeds, Res. Vet. Sci., 72, 69-73, https://doi.org/10.1053/rvsc.2001.0525, 2002.

Khanshour, A., Conant, E., Juras, R., and Cothran, E. G.: Microsatellite analysis of genetic diversity and population structure of Arabian horse populations, J. Hered., 104, 386-398, https://doi.org/10.1093/jhered/est003, 2013.

LeCompte, M. L.: The Hispanic influence on the history of rodeo, 1823-1922, J. Sport. Hist., 12, 21-38, 1985.

Leroy, G., Callède, L., Verrier, E., Mériaux, J. C., Ricard, A., Danchin-Burge, C., and Rognon, X.: Genetic diversity of a large set of horse breeds raised in France assessed by microsatellite polymorphism, Genet. Sel. Evol., 41, 5, https://doi.org/10.1186/1297-9686-41-5, 2009.

Ling, Y. H., Ma, Y. H., Guan, W. J., Cheng, Y. J., Wang, Y. P., Han, J. L., Mang, L., Zhao Q. J., He, X. H., Pu, Y. B., and Fu, B. L.: Evaluation of the genetic diversity and population structure of Chinese indigenous horse breeds using 27 microsatellite markers, Anim. Genet., 42, 56-65, https://doi.org/10.1111/j.13652052.2010.02067.x, 2011.

Loroño-Pino, M. A., Blitvich, B. J., Farfán-Ale, J. A., Puerto, F. I., Blanco, J. M., Marlenee, N. L., Rosado-Paredes, E. P., García-Rejón, J. E., Gubler, D. J., Calisher, C. H., and Beaty, B. J.: Serologic evidence of West Nile virus infection in horses, Yucatan State, Mexico, Emerg. Infect. Dis., 9, 857-859, https://doi.org/10.3201/eid0907.030167, 2003.

Luís, C., Bastos-Silveira, C., Cothran, E. G., and Oom, M. M.: Iberian origins of New World horse breeds, J. Hered., 97, 107113, https://doi.org/10.1093/jhered/esj020, 2006.

Luis, C., Juras, R., Oom, M. M., and Cothran, E. G.: Genetic diversity and relationships of Portuguese and other horse breeds based on protein and microsatellite loci variation, Anim. Genet., 38, 20-27, https://doi.org/10.1111/j.1365-2052.2006.01545.x, 2007.

Marletta, D., Tupac-Yupanqui, I., Bordonaro, S., Garcia, D., Guastella, A. M., Criscione, A., Cañon, J., and Dunner, S.: Analysis of genetic diversity and the determination of relationships among western Mediterranean horse breeds using microsatellite markers, J. Anim. Breed. Genet., 123, 315-325, https://doi.org/10.1111/j.1439-0388.2006.00603.x, 2006.

Mirol, P. M., Peral, G. P., Vega-Pla, J. L., and Dulout, F. N.: Phylogenetic relationships of Argentinean Creole horses and other South American and Spanish breeds inferred from mitochondrial DNA sequences, Anim. Genet., 33, 356-363, https://doi.org/10.1046/j.1365-2052.2002.00884.x, 2002.
Nájera-Ramírez, O.: Engendering nationalism: identity, discourse, and the Mexican charro, Anthropol. Q., 67, 1-14, https://doi.org/10.2307/3317273, 1994.

Nei, M., Maryama, T., and Chakraborty, R.: The bottleneck effect and genetic variability in populations, Evolution, 29, 1-10, https://doi.org/10.2307/2407137, 1975.

Palomar, C.: El papel de la charrería como fenómeno cultural en la construcción del occidente de México, Rev. Eur. Estud. Latinoam. Caribe, 76, 83-98, 2004.

Petersen, J. L., Mickelson, J. R., Cothran, E. G., Andersson, L. S., Axelsson, J., Bailey, E., Bannasch, D., Binns, M. M., Borges, A. S., Brama, P., and da Câmara M. A.: Genetic diversity in the modern horse illustrated from genome-wide SNP data, PLoS One, 8, e54997, https://doi.org/10.1371/journal.pone.0054997, 2013.

Pineda, M. P. and Díaz, A. O.: El galope del caballo en México, Chedraui RF Editor, Editorial Las Ánimas S. A. de C. V. 1a ed. México, 2012.

Piry, S., Alapetite, A., Cornuet, J. M., Paetkau, D., Baudouin, L., and Estoup, A.: GeneClass2: A software for genetic assignment and first-generation migrant detection, J. Hered., 95, 536-539, https://doi.org/10.1093/jhered/esh074, 2004.

Pritchard, J. K., Stephens, M., and Donnelly, P.: Inference of population structure using multilocus genotype data, Genetics, 155 , 945-959, 2000.

Prystupa, J. M., Juras, R., Cothran, E. G., Buchanan, F. C., and Plante, Y.: Genetic diversity and admixture among Canadian, Mountain and Moorland and Nordic pony populations, Animal, 6, 19-30, https://doi.org/10.1017/S1751731111001212, 2012.

Raudsepp, T., Gustafson-Seabury, A., Durkin, K., Wagner, M. L., Goh, G., Seabury, C. M., Brinkmeyer-Langford, C., Lee, E.-J., Agarwala, R., Stallknecht-Rice, E., Schäffer, A. A., Skow, L. C., Tozaki, T., Yasue H., Penedo, M. C. T., Lyons, L. A., Khazanehdari, K. A., Binns, M. M., MacLeod, J. N., Distl, O., Guérin, G., Leeb, T., Mickelson, J. R., and Chowdhary, B. P.: A 4,103 marker integrated physical and comparative map of the horse genome. Cytogen Gen Res, 122, 28-36. doi: 10.1159/000151313, 2008.

Rodríguez-Sánchez, I. P., Treviño-Alvarado, V. M., TorresSepúlveda, M. R., López-Saldaña, L. A., Ponce-García, G., López-Uriarte, G. A., Ruiz-Herrera, M. C., Zamora-Ávila D. E., Villarreal-Pérez, J. Z., Dávalos-Aranda, G., and Martínez-de-Villarreal, L. E.: Reference values for amino acids and acylcarnitines in peripheral blood in Quarter horses and American Miniature horses, Acta Vet. Scand., 57, 62, https://doi.org/10.1186/s13028-015-0144-9, 2015.

Sánchez-Casanova, R. E., Masri-Daba, M., Alonso-Díaz, M. Á, Méndez-Bernal, A., Hernández-Gil, M., and Fernando-Martínez, J. A.: Prevalence of cutaneous pathological conditions and factors associated with the presence of skin wounds in working equids in tropical regions of Veracruz, Mexico, Trop. Anim. Health. Prod., 46, 555-561, https://doi.org/10.1007/s11250-0130529-6, 2014.

Solis, A., Jugo, B. M., Mériaux, J. C., Iriondo, M., Mazón, L. I., Aguirre, A. I., Vicario, A., and Estomba, A.: Genetic diversity within and among four South European native horse breeds based on microsatellite DNA analysis: implications for conservation, J. Hered., 96, 670-678, https://doi.org/10.1093/jhered/esi123, 2005. 
Takasu, M., Hiramatsu, N., Tozaki, T., Kakoi, H., Nakagawa, T., Hasegawa, T., Huricha M. M., Murase, T., and Mukoyama, H.: Genetic characterization of the endangered Kiso horse using 31 microsatellite DNAs, J. Vet. Med. Sci., 74, 161-166, https://doi.org/10.1292/jvms.11-0025, 2012.

van de Goor, L. H., Panneman, H., and van Haeringen, W. A.: A proposal for standardization in forensic equine DNA typing: allele nomenclature for 17 equine-specific STR loci, Anim. Genet., 41, 122-127, https://doi.org/10.1111/j.1365-2052.2009.01975.x, 2010.

van de Goor, L. H., van Haeringen, W. A., and Lenstra J. A.: Population studies of 17 equine STR for forensic and phylogenetic analysis, Anim. Genet., 42, 627-633, https://doi.org/10.1111/j.13652052.2011.02194.x, 2011.
Velázquez-Beltrán, L. G., Sánchez-Vera, E., Nava-Bernal, E. G., and Arriaga-Jordán, C. M.: The role of working equines to livelihoods in current day campesino hill-slope communities in central Mexico, Trop. Anim. Health Prod., 43, 1623-1632, https://doi.org/10.1007/s11250-011-9881-6, 2011.

Zuccaro, A., Bordonaro, S., Criscione, A., Guastella, A. M., Perrotta, G., Blasi, M., D’Urso, G., and Marletta, D.: Genetic diversity and admixture analysis of Sanfratellano and three other Italian horse breeds assessed by microsatellite markers, Animal, 2, 991-998, https://doi.org/10.1017/S1751731108002255, 2008. 